\title{
„Zdrajcy narodu” - elementy gnozy politycznej w procesie demaskacji wroga wewnętrznego w Rosji'
}

\begin{abstract}
Celem artykułu jest pokazanie, w jaki sposób na potrzeby aktualnej polityki wewnętrznej elita kremlowska konstruuje obraz opozycji niesystemowej w Rosji jako wroga wewnętrznego, zdrajcę narodu oraz marginalizuje wszystkie działania ruchów niesystemowych. Wykorzystywanie przez Kreml binarnej struktury „wróg-przyjaciel” oraz działania przeciwko wrogowi, jakim jest opozycja niesytemowa, potwierdza obecność elementów dojrzałej gnozy politycznej w Rosji Władimira Putina.
\end{abstract}

Stowa kluczowe: Rosja, gnoza polityczna, władza

Tematem poniższego artykułu jest kwestia obrazu opozycji niesystemowej we współczesnej Rosji ze szczególnym uwzględnieniem sposobów konstruowania przez elitę kremlowską na potrzeby aktualnej polityki wewnętrznej wizerunku opozycji niesystemowej jako wroga wewnętrznego, wichrzyciela porządku, zdrajcy ojczyzny.

Opozycją niesystemową w Rosji nazywamy te ugrupowania, ruchy polityczne, grupy społeczne, które krytycznie odnoszą się do obecnego systemu politycznego (umownie nazywanego putinizmem lub systemem Putina), koncentrując wysiłki na próbach zmiany tego systemu².

\footnotetext{
${ }^{1}$ Tekst artykułu powstał w oparciu o badania przeprowadzone w ramach projektu NCN „Opozycja niesystemowa w Rosji - rola i znaczenie w rosyjskiej polityce wewnętrznej” (numer UMO2014/13/D/HS5/00637).

${ }^{2}$ Do najważniejszych opozycjonistów niesystemowych zalicza się m.in. Aleksieja Nawalnego, Ilję Jaszyna, twórcę projektu „Otwarta Rosja” Michaiła Chodorkowskiego, Michaiła Kasjanowa,
} 
Tak przyjęta definicja opozycji niesystemowej pozwala w najpełniejszy sposób oddać charakter tego zjawiska we współczesnej Rosji ${ }^{3}$. Zasadność takiej wykładni pojęcia ,niesystemowa opozycja w Rosji” wynika z faktu, że jest to struktura niejednorodna i nie wyczerpuje jej prosta klasyfikacja na partie koncesjonowane i niekoncesjonowane. Opozycja niesystemowa w Rosji jest faktycznie opozycją wobec władzy, w przeciwieństwie do opozycji systemowej, którą można określić jako opozycję przy władzy, czyli w gruncie rzeczy lojalną wobec elity kremlowskiej i będącą elementem tzw. limitowanego pluralizmu w Rosji.

Wielu autorów uważa, że należy rozgraniczyć opozycję niesystemową od ekstremistów i grup o radykalnym charakterze. Te ostatnie „okazują się niesystemowe w relacji do społeczeństwa jako meta-systemu, posiadającego wyższe wartości moralne i dlatego wymagające odpowiedniego względem siebie stosunku"4. Daria Tatarkowa uważa, że należy niesystemową opozycję scharakteryzować jako organizacje, ruchy przeciwstawiające się obecnemu reżimowi i elicie władzy, uznające legitymizowany przez większość społeczeństwa system politycznych wartości oraz nie noszące ekstremistycznego charakteru ${ }^{5}$.

Mówiąc o opozycji w Rosji ważne jest, by dostrzec fakt, że to Putin jest kluczową postacią w kontekście rozmowy o systemowej i niesystemowej opozycji. To właśnie stosunek do prezydenta wyznacza fundamentalną różnicę między obiema strukturami. Partię zalicza się do niesystemowej, jeśli doprowadzenie do odsunięcia Putina ze stanowiska prezydenta jest jej kluczowym celem. I na odwrót: partię można zaliczyć do systemowej, jeżeli odsunięcie Putina nie jest dla niej warunkiem sine qua non sukcesu i celem działania ${ }^{6}$. Mówimy system polityczny - myślimy Putin i na odwrót.

\section{Gnoza polityczna}

Wyjaśnienie sposobów deprecjonowania przez Kreml rosyjskiej opozycji niesystemowej wymaga odwołania się do terminu gnoza polityczna, której elementy wykorzystuje rosyjska władza. Jak zaznacza Romana Bäcker w swoim tekście Język a władza. Między totalitarna gnoza polityczna a statokratyzmem.

\footnotetext{
Garrego Kasparowa, Władimira Miłowa, Władimira Ryżkowa, Ilję Ponomariowa, Siergieja Udalcowa.

3 Tym samym zrezygnowałam z ogólnie przyjętego w systemach demokratycznych określenia opozycji niesystemowej jako ugrupowań, którym odmawia się rejestracji, czy pozostających poza parlamentem.

${ }^{4}$ Ю. Волков, Социальные системы как обект сочиологическово анализа, „Социс” $2009 \mathrm{nr}$ 9, s. 120.

5 Д.Ю. Татаркова, Несистемная оппозициякакспецифика презентации в печатных СМИ, „Полис" 2013, nr 04, s. 132.

${ }^{6}$ О возвращении несистемной оппозиции, http://www.ng.ru/editorial/2015-04-21/2_red.html [22.06.2015].
} 
Język oficjalnych wypowiedzi państwowo-partyjnych funkcjonariuszy PRL w latach 1981-1989 totalitarna gnoza polityczna „charakteryzuje się istnieniem skrajnie negatywnego obrazu wroga - odpowiedzialnego za wszelkie istniejące zło i przeszkadzającego (obiektywnie) w urzeczywistnianiu dzieła doczesnego zbawienia" ". Pod pojęciem gnozy politycznej rozumiemy zamknięty system myślenia, wykluczający pluralizm światopoglądowy i przypominający „świecką religię”. Atmosfera osaczenia przez wrogów, zarówno tych zewnętrznych, jak i wewnętrznych, jest ważnym elementem składowym rosyjskiego systemu, który ma uzasadniać własne zamknięcie się na wszystkich myślących inaczej niż obecna władza ${ }^{8}$.

Gnoza jest według Erica Voegelina największą herezją oraz wypaczeniem w historii ludzkości - wszystko dlatego, że ,gnostyk jest tym, który, wedle własnego mniemania, wie nie tylko, jak wygląda idealna rzeczywistość, ale również jak ją zaprowadzić"’.

W odniesieniu do Rosji odwołania do gnozy politycznej widać w dyskursie elity kremlowskiej. To ona ma receptę na zaprowadzenie idealnego ładu, porządku w kraju, ale ta idealna wizja nie ziści się dopóki istnieją siły zła w postaci przeciwników Kremla. Uruchamiane są w tym celu binarne struktury myślenia i klarowne, nie rodzące wątpliwości przekazy dotyczące tego, kto jest wrogiem, czyli tym, kogo należy zniszczyć, żeby nie rozprzestrzeniał zgnilizny i degeneracji. Sam obraz wroga może się zmieniać w zależności od okoliczności, jednak schemat „swój-obcy” pozostaje niezmienny.

Jak słusznie pisał Michał Głowiński, ,przeciwstawienie my-wy czy naszwasz może być wypełnione rozmaitymi treściami, może być nasycane różnymi konkretami, o istocie sprawy decyduje to, że nam, czyli tym, którzy posiedli słuszność, przeciwstawiany jest wyraźnie nazwany przeciwnik (wyraźnie nazwany także wówczas, gdy jest tworem fikcyjnym czy półfikcyjnym)"10.

W tak skonstruowanym schemacie zmienne „x” - czyli „my”, „nasz”, „obóz światła i porządku” oraz „y” - „oni”, „wróg”, „obóz mroku i chaosu” mogą być

7 R. Bäcker, Język a władza. Między totalitarna gnoza polityczna a statokratyzmem. Język oficjalnych wypowiedzi państwowo-partyjnych funkcjonariuszy PRL w latach 1981-1989, [w:] Kulturowe instrumentarium panowania, red. P. Załęcki, R. Paradowski, Torun 2001, s. 61, zob. http://www.home.umk.pl/ zalecki/txt/instrumentarium.html [dostęp: 1.09.2015].

8 Więcej o gnozie politycznej przeczytać można w monografii Gnoza polityczna, red. J. Skoczyński, Kraków 1998.

9 T. Niezgoda, Recepcja Joachima z Fiore w średniowiecznych ruchach heretyckich $w$ świetle koncepcji gnozy politycznej, „Ex nihilo” 2012, 1 (7), s. 36.

${ }^{10} \mathrm{M}$. Głowiński, $O$ dyskursie totalitarnym, [w:] tenże, Dzień Ulissesa $i$ inne szkice na tematy niemitologiczne, Kraków 2000, s. 38-39, cyt za: J. Sadowski, Między Pałacem Rad a Pałacem Kultury. Studium kultury totalitarnej, Kraków 2009, s. 51. 
wypełnione rozmaitymi treściami. Najważniejszy jest jednak fakt, że sam kościec tego binarnego schematu pozostaje nienaruszony. Wzór x i y sprawdza się wyjątkowo dobrze zarówno wobec chaosu nadciągającego z zewnątrz, jak i wobec wewnętrznych wichrzycieli ${ }^{11}$.

Mając na uwadze powyższe rozważania możemy wspomnieć definicję mitologii politycznej rosyjskiego uczonego Andrieja Toporkowa, który pisał, iż nie odzwierciedla ona rzeczywistości, lecz służy zarządzaniu zbiorową świadomością i zachowaniem mas ludzkich. Polityczna mitologia ma być prosta i oczywista, nie powinna operować abstrakcyjnymi pojęciami, lecz zrozumiałymi wizualnie i łatwymi do zakodowania symbolami: „,wróg”, „przyjaciel”,

O współczesnym odwoływaniu się do tego schematu w Rosji mówił zmarły niedawno rosyjski historyk, Jurij Afanasjew:

Dzisiejsze rosyjskie władze odwołują się do przechowanych w rosyjskiej świadomości pradawnych wyobrażeń o należnych nam z Boskiego nadania bezkresnych ruskich ziemiach, o otaczających nas wrogich siłach Mroku, Zła i Nieprawości i o ruskiej władzy będącej jedyną szansą przetrwania dla całej społeczności ${ }^{13}$.

Dziś przeciwnicy, krytycy rosyjskiej władzy, otrzymują etykietkę „piątej kolumny", oznaczającą grupę prowokatorów, bojowników lub dystrybutorów paniki, gotowych do buntu przeciwko prawowitej władzy, „zdrajców narodu”, czy ,agentów zagranicznych”. Tak prowadzona narracja ma ugruntować w rosyjskim społeczeństwie przekonanie, że niczego pozytywnego nie można się spodziewać po osobach zaklasyfikowanych do wyżej wymienionych grup.

\section{Opozycja niesystemowa jako rosyjski odpowiednik Zachodu}

Opozycję niesystemową łatwo oskarżyć o ideowe powinowactwo z Zachodem, ze względu na odwoływanie się do wartości takich jak demokracja, liberalizm, szczególnie cenionych właśnie w państwach cywilizacji zachodniej oraz nawiązania do zachodnich wzorców ustrojowych w programach ugrupowań opozycyjnych.

\footnotetext{
${ }^{11}$ J. Sadowski, Między Pałacem Rad a Pałacem Kultury. Studium kultury totalitarnej, Kraków 2009, s. 51.

${ }^{12}$ А.Л. Топорков, Мифы и мифология ХХ века: традиция и современное восприятие, $\mathrm{http}: / /$ www.ruthenia.ru/folklore/toporkov1.htmz [10. 06. 2011].

${ }^{13}$ Jurij Afanasjew: Chcialbym odczarować Rosję. [ADAM MICHNIK żegna przyjaciela], http://wyborcza.pl/magazyn/1,148049,18850836,jurij-afanasjew-chcialbym-odczarowac-rosjeadam-michnik-zegna.html [10.10.2015].
} 
Rosyjski krytyka Zachodu wydaje się na tyle głęboko zakotwiczona w rosyjskiej kulturze, że wystarczy uruchomić pewne struktury myślenia i mechanizmy oceniające, aby uzyskać efekt deprecjacji państw zachodnich. Dewaluacja Zachodu przybiera co prawda nową treść, dostosowaną do dzisiejszych warunków oraz okoliczności, podstawa jednak - oparta na przeświadczeniu o zepsuciu moralnym świata zachodniego - pozostaje niezmienna.

W wielu wystąpieniach publicznych Władimir Putin posiłkuje się argumentami dotyczącymi zepsucia i braku wyższych wartości na Zachodzie, by tym samym zminimalizować zachwyt rosyjskiego społeczeństwa nad zachodnimi osiągnięciami oraz ograniczyć społeczne dążenia do naśladowania państw zachodnich. W jubileuszowym wystąpieniu w Klubie Wałdajskim we wrześniu 2013 roku, jeszcze przed kryzysem ukraińskim prezydent Rosji mówił o konieczności uwolnienia się od prób naśladowania Zachodu, ponieważ niemożliwe jest zaszczepienie idei innych krajów na rodzimy grunt, kopiowanie cudzych doświadczeń:

Takie intensywne zapożyczenia, próby cywilizowania Rosji z zewnątrz nie były przyjęte przez absolutną większość naszego narodu, ponieważ dążenie do samodzielności duchowej, ideologicznej, suwerenności w zakresie podejmowanych decyzji jest nieodłączną częścią naszego narodowego charakteru ${ }^{14}$.

Nie można tworzyć państwowości według gotowego, zewnętrznego modelu, wzoru, wgrywać państwu nowy program, jak do komputera. W zaakcentowaniu różnic między Rosją i Zachodem i wymogu uwolnienia się od prób naśladowania Zachodu Putin poszedł jeszcze o krok dalej. Jasno i wyraźnie zaznaczył, że po prostu nie ma czego naśladować, bo Zachód jest martwy. Swój wywód o „zgniłym Zachodzie” rozpoczął od krytycznej refleksji nad kondycją moralną krajów zachodnich:

Widzimy, jak liczne euroatlantyckie kraje faktycznie poszły w stronę odrzucenia swoich korzeni, w tym i chrześcijańskich wartości, stanowiących podstawę zachodniej cywilizacji. Podważa się wszystkie aspekty tożsamości: narodowej, kulturalnej, religijnej, a nawet płciowej. Na Zachodzie prowadzi się politykę, która na jednym poziomie stawia wielodzietną rodzinę i życie w pojedynkę, wiarę w Boga i wiarę w szatana. Ekscesy poprawności politycznej doprowadzają do tego, że rozmawiamy o rejestracji partii, stawiających sobie za cel propagandę pedofiliil ${ }^{15}$.

\footnotetext{
${ }^{14}$ Выступление Владимира Путина на заседании клуба „Валдай”, http://www.rg.ru/ 2013/09/19/ stenogramma-site.html [17.09.2015].

15 Tamże.
} 
Dziwna poprawność polityczna Zachodu ujawnia się również w kontekście oceny Silvio Berlusconiego - mówił prezydent Rosji:

Berlusconiego sądzą teraz za to, że żyje z kobietami. Oczywiście, jeśli byłby homoseksualistą, to nikt by go palcem nie tknął. Ludzie w europejskich krajach wstydzą się i boją się mówić o swojej religijnej przynależności. Święta unieważniają albo nazywają je jakoś inaczej, wstydliwie ukrywając samą istotę świąt - ich moralną podstawę. I ten model próbują agresywnie narzucać wszystkim, całemu światu. Jestem przekonany, że to prosta droga do degradacji i prymitywizacji, głębokiego demograficznego i moralnego kryzysu. Bez wartości wynikających z chrześcijaństwa i innych światowych religii, bez kształtujących się tysiącleciami norm moralnych ludzie nieuchronnie utracą swoje człowieczeństwo. Trzeba szanować prawo każdej mniejszości, ale też prawo większości nie powinno być poddawane w wątpliwośćc ${ }^{16}$.

Opisana $\mathrm{w}$ ten sposób degradacja moralna Zachodu, wyzbycie się przez świat zachodni tradycji chrześcijańskiej i duchowych wartości jest dla rosyjskiej elity rządzącej wystarczającą przesłanką dla konstatacji, że wszyscy ci, którzy nawołują do absorpcji zachodnich wartości, działają na szkodę Rosji i wyzbyli się uczuć patriotycznych. Idąc dalej tym sposobem myślenia: skoro Zachód to demokracja liberalna, a Władimir Putin zdemaskował Zachód, obnażył jego „zgniliznę duchową" i upadek obyczajów, to również wszyscy ci, którzy mówią o konieczności zmiany władzy w Rosji, krytykują porządek zaprowadzony przez Władimira Putina i dążą do liberalizacji systemu i demokratyzacji na wzór zachodni nie są patriotami. W ten sposób mamy konstrukcję zero-jedynkową: albo popierasz Władimira Putina, albo nie jesteś patriotą. Tertium non datur.

Wzrost uczuć patriotycznych utożsamiany jest często ze zjednoczeniem się wokół prezydenta, wsparciem jego polityki oraz przekonaniem, że zwolennicy Zachodu chcą tę jedność podważyć ${ }^{17}$. Dochodzimy więc do miejsca, w którym ważnym elementem staje się opis społecznej reakcji na sposoby konstruowania rzeczywistości przez elitę kremlowską.

\section{Wykorzystanie nastrojów społecznych}

Aleksiej Lewinson z niezależnego Centrum Lewady oraz Liubow Borusiak z Wyższej Szkoły Ekonomii w Moskwie podkreślają, że nienawiść Rosjan do Ameryki i „piątej kolumny" nie są wynikiem propagandy. Zdaniem autorów, oburzenie Rosjan już od dawna dojrzewa w rosyjskim społeczeństwie, natomiast te-

\footnotetext{
16 Tamże.

17 Л. Борусяк, А. Левинсон, Анатомия ненависти: как возникло посткрымское единство россиян, http://www.rbc.ru/opinions/society/18/03/2015/550973de9a794732 7e5f3a1c [24.10.2015].
} 
lewizja i inne prokremlowskie media skutecznie wykorzystują te emocje i wskazują kolejnych wrogów, odpowiedzialnych za niepowodzenie Rosjan.

Propaganda oczywiście może odpowiadać za podniesienie poziomu nienawiści, wytwarzać i rozpowszechniać nowe argumenty wspierające określoną wizję rzeczywistości i eksponujące wroga, ale nie uruchamia nienawiści jako takiej $^{18}$. Potwierdza to również dyrektor Centrum Lewady, Lew Gudkow. Według niego ludzie są gotowi uwierzyć w coś, co oferuje im propaganda, ponieważ ta oferta odpowiada ich obrazowi rzeczywistości. Wszystkie motywy przypisywane Zachodowi i tak zwanym wrogom wewnętrznym, są zrozumiałe dla ludzi, ponieważ to są ich własne struktury świadomości ${ }^{19}$.

Putin to personifikacja masowych wyobrażeń, ich średnia arytmetyczna. Putin jest kimś w rodzaju aktywatora, czy katalizatora utajonych pragnień, oczekiwań społecznych - mówi socjolog.

Powyższa analiza koresponduje ze słowami pisarza i dziennikarza, Walerego Paniuszkina, który łatwość społecznej recepcji narracji o wrogach zewnętrznych i wewnętrznych objaśnia opisywanym przez psychologów społecznych syndromem posttraumatycznym ${ }^{20}$.

Takim traumatycznym przeżyciem dla Rosjan był rozpad Związku Radzieckiego. Pierwszym etapem radzenia sobie z traumą jest negacja, wyparcie. Ten etap, zdaniem Paniuszkina, społeczeństwo rosyjskie już przeszło. Następnym etapem jest uczucie gniewu. I właśnie w tym miejscu, według pisarza, znajduje się obecnie społeczeństwo rosyjskie. To etap, gdy gniew rozprzestrzeniany jest na wszystkie podmioty, które odbierane są jako wewnętrzni i zewnętrzni wrogowie ${ }^{21}$. Syndrom posttraumatyczny w pewnym stopniu pokrywa się z syndromem „oblężonej twierdzy”, za pomocą którego rosyjska władza stara się przekonać społeczeństwo o istnieniu wrogów Rosji, którzy chcą ją zniszczyć. Listę podmiotów, najbardziej zagrażających rosyjskim interesom, otwierają Stany Zjednoczone. Na kolejnych miejscach są również inne państwa zachodnie. Wewnętrznym zagrożeniem jest przenikanie do Rosji zachodnich idei, a wrogiem - podmioty, które starają się je rozprzestrzeniać.

\footnotetext{
${ }^{18}$ Tamże.

${ }^{19}$ Е. Фельдман в беседе с директором левада-центра Львом Гудковым, Тоталитарный дрей yi-dreif [25.10.2015].

${ }^{20}$ Syndrom posttraumatuczny jest opisany przez Elisabeth Kübler-Ross w jej klasycznej pracy Rozmowy o śmierci i umieraniu.

${ }^{21}$ Trzecim etapem jest rozpacz. Kolejnym etapem jest prośba po pomoc; W. Paniuszkin, Rosja jakiej nie znacie, https://www.youtube.com/watch?v=-vbM0ka9QOg [04.12.2014].
} 
Lewinson i Borusiak wskazują, że ważnym elementem nienawiści wobec określonej grupy „obcych” jest możliwość łatwego przeniesienia negatywnych uczuć na inną grupę. Mechanizm ten możemy zaobserwować w przypadku porównania czasów, kiedy Rosjanie za nieszczęścia w swoim życiu oskarżali przyjezdnych z Azji Środkowej z dzisiejszymi, gdy te same zarzuty formułowane są wobec Zachodu, czy „piątej kolumny”, a więc rodzimych demokratów.

System wskazywania wrogów jest wspierany przez rosyjskich decydentów politycznych, którzy - zdaniem autorów analizy - mają świadomość, że bez wskazywania „wroga”, „obcego”, skumulowaną nienawiść obrócą przeciwko „swoim”, elicie rządzącej, czyli tym, którzy de facto odpowiadają za sytuację w kraju ${ }^{22}$.

$\mathrm{W}$ przypadku tak silnie negatywnych emocji nagromadzonych $\mathrm{w}$ społeczeństwie rosyjskim elita kremlowska zdaje sobie sprawę, że albo wykorzysta je jako podporę reżimu i element mobilizacji społecznej, wskazując winnych obecnej sytuacji, albo sama stanie się adresatem tej fali niezadowolenia.

Dlatego też rosyjskich ekspertów nie dziwi fakt, że w ostatnich kilkunastu miesiącach po aneksji Krymu głównym wrogiem Rosji, wskazywanym w sondażach opinii publicznej, stała się ,piąta kolumna”. Propagandowa gleba, która pozwoliła kierunkować nienawiść wobec opozycji niesystemowej została przygotowana już wcześniej, kiedy po protestach z lat 2011/2012 władza szukała sposobów na zdewaluowanie swoich oponentów. Kompromitującym opozycję w oczach społeczeństwa materiałem był film Anatomia protestu, wyemitowany na kanale NTV, w którym autorzy próbują udowodnić tezę, że protestujący działali z inspiracji Zachodu, głównie Ameryki, a ich celem było zburzenie porządku społeczno-politycznego w Rosji i zaprowadzenie chaosu. Na fali rosnącej nienawiści do Ameryki ekipa rządząca w Rosji nie miała większych trudności ze stworzeniem koncepcji związków, bliskich relacji między opozycją rosyjską a Ameryką. Owa więź pozwoliła na zniesienie podziałów na wroga wewnętrznego oraz zewnętrznego. Wróg jest jeden i wszechobecny.

W przypadku ,piątej kolumny” i wzmacniania nienawiści wobec niej istotny był - zdaniem Lewinsona i Borusiak - związek trzech ważnych czynników. Pierwszy - to opisany wyżej mechanizm przeniesienia nienawiści; drugi - to uzyskanie z góry komendy charakterystycznej dla sytuacji tresowania czworonogów, czyli „brać go”; trzeci - gotowość techniczna rosyjskiego systemu propagandowego, przede wszystkich głównych kanałów telewizyjnych, do uderzenia w „piątą kolumnę" i Amerykę $e^{23}$.

\footnotetext{
${ }^{22}$ Л. Борусяк, А. Левинсон, Анатомия ненависти...

${ }^{23}$ Tamże.
} 
Istotną rolę w zwiększeniu przekazów deprecjonujących opozycję niesystemową i działań zmierzających do jej zmarginalizowania w życiu politycznospołecznym odegrała sytuacja na Ukrainie, a w szczególności rewolucja godności.

Aneksja Krymu, zdaniem Lilii Szewcowej - ekspertki The Brookings Institution - nie była wyrazem chęci ochrony osób rosyjskojęzycznych. Prestiż Kremla też był sprawą drugorzędną. Najważniejszym motywem według Szewcowej była obawa przed wyczerpywaniem się systemu samodzierżawia. Majdan stanowił ostrzeżenie, że społeczeństwa w przestrzeni poradzieckiej coraz częściej poszukują alternatywy dla rządów autorytarnych. Dlatego, jeśli chodzi o tendencję rozwoju systemu rosyjskiego, zdaniem ekspertki będzie on coraz bardziej zbliżał się do totalitaryzmu ${ }^{24}$.

Niewątpliwie skutki zaostrzenia reżimu odczuje rosyjska opozycja niesystemowa. Izolacja Rosji po aneksji Krymu i ochłodzenie relacji z Zachodem sprawi, że Kreml przestanie zabiegać o swój wizerunek zagranicą i nie będzie nawet starał się uzasadniać polityki „dokręcania śruby” - twierdzi Szewcowa.

\section{Niszczenie wroga i język mowy totalitarnej}

W związku z wydarzeniami na Ukrainie w Rosji rozszerzył się zakres kompetencji organizacji prokremlowskich zwalczających opozycję. Fenomenem są bojówki „Antymajdanu”. Pisała o tym we wrześniu 2014 roku gazeta „Izwiestia”:

W rosyjskich regionach zaczęło się formowanie drużyn antymajdanowych, które wspólnie z organami prawa i porządku będą zapobiegać antypaństwowym, prowokacyjnym, agresywnym działaniom opozycji niesystemowej, celem których jest zmiana ustroju konstytucyjnego ${ }^{25}$.

Na stronie internetowej ruchu „Antymajdan” czytamy manifest jego aktywistów:

Złączyliśmy się w ruch Antymajdan, ponieważ kochamy Rosję i chcemy zachować oraz ochronić nasz wielki kraj. Działamy razem, aby zapobiec kolorowym rewolucjom, ulicznym rozruchom, chaosowi i anarchii. Nie pozwolimy, by naszymi miastami rządziły siły, które nienawidzą silnej i suwerennej Rosji i które posiadają aprobatę i wsparcie z zagranicy. Wierzymy, że tylko suwerenna Rosja może zapewnić godne życie swoim obywatelom. W związku z tym wszystkie kluczowe decyzje doty-

\footnotetext{
24 Л. Шевцова, Как Россия возвращһает мир к ожиданию войны, http://www.ej.ru/ $? \mathrm{a}=$ note \&id=24692 [19.09.2015].

${ }^{25}$ В России началось формирование антимайданных дружин, http://izvestia.ru/ news/576041 [24.10.2015].
} 
czące życia naszego narodu muszą być podejmowane w Moskwie, a nie w Waszyngtonie i Brukseli. [...] Widzimy tragedię Ukrainy, gdzie bratobójcza wojna w Donbasie zaczęła się na Majdanie, od demonstracji ulicznych i zamieszek. Zdecydowanie stwierdzamy, iż nie dopuścimy do siłowego obalenia legalnie wybranej władzy, bez względu na to, jakimi pięknymi sloganami ta przemoc będzie tuszowana ${ }^{26}$.

Wśród założycieli ruchu „Antymajdan” znajduje się między innymi Aleksander Załdostanow - przywódca nacjonalistycznego klubu motocyklowego „Nocne Wilki”, Dmitrij Sablin - emerytowany pułkownik, członek Rady Federacji, jeden z liderów organizacji „Bractwo Bojowe”, która skupia weteranów wojennych i byłych wojskowych, oraz pisarz i publicysta Nikołaj Starikow.

Ruch „Antymajdan” to powstała z inicjatywy Kremla imitacja oddolnego ruchu obywatelskiego. Organizacja po pierwsze pozwala na konsolidację radykalnie nastawionych sprzymierzeńców władzy, a po drugie pomaga tej ostatniej zwalczać oponentów politycznych bez formalnego wykorzystania struktur państwowych $^{27}$. Aktywiści „Antymajdanu” nie tylko nie wykluczają używania przemocy, ale wyraźnie deklarują, że przeciwników silnej i suwerennej Rosji, a więc w domyśle - Rosji Putina - będą niszczyć.

Niszczenie wrogów systemu musi być jednak w oczach społeczeństwa rosyjskiego działaniem zasadnym, dlatego Kreml radykalizuje język opisujący przeciwników politycznych.

W czasie wystąpienia w marcu 2014 do Zgromadzenia Federalnego Władimir Putin mówił o ,piątej kolumnie” i ,zdrajcach narodu” ${ }^{28}$ :

Niektórzy politycy zachodni już straszą nas nie tylko sankcjami, lecz i perspektywą zaostrzenia problemów wewnętrznych. Chciałoby się wiedzieć, co mają oni na uwadze: działania pewnej piątej kolumny - różnego rodzaju narodowych zdrajców - czy też pogorszenie sytuacji społeczno-ekonomicznej Rosji i tym samym sprowokowanie niezadowolenia ludzi ${ }^{29}$

Elita rządząca próbuje wzbudzać negatywne asocjacje również w przypadku organizacji pozarządowych pozyskujących fundusze na działalność z zagranicy, prawnie sankcjonując określanie ich ,agentami zagranicznymi”. Już w 2011 roku Putin nazwał organizacje pozarządowe otrzymujące dofinansowanie z zagranicy ,pseudo-

\footnotetext{
${ }^{26}$ Манифест, http://antimaidan.ru/page/9 [12.10.2015].

${ }^{27} \mathrm{~K}$. Chawryło, Antymajdan $w$ Rosji - nowy instrument Kremla $w$ walce z opozycja, $\mathrm{http} / /$ www.osw.waw.pl/pl/publikacje/analizy/2015-01-21/antymajdan-w-rosji-nowy-instrumentkremla-w-walce-z-opozycja [23.10.2015].

${ }^{28}$ С. Павлова, Национал-предатели Путина, http://www.svoboda.org/content/article/ 25302687. $\mathrm{html}[13.10 .2015]$.

${ }^{29}$ Tamże.
} 
organizacjami pozarządowymi”, zarzucając im zdradę. Charakteryzując te podmioty wykorzystał nawet biblijne porównanie, mówiąc, iż „Judasz nie jest w naszym narodzie szczególnie poważaną postacią"30.

W 2012 roku prezydent Rosji podpisał tzw. ustawę o agentach zagranicznych, według której organizacje finansowane z zagranicznych funduszy muszą być rejestrowane jako „organizacje pełniące funkcje zagranicznych agentów”, a także wyraźnie opisane $\mathrm{w}$ ten sposób we wszystkich materiałach publicznych, jeśli władze uznają, że angażują się w „działalność polityczną, ${ }^{31}$.

Mimo ostrej krytyki ustawy przez obrońców praw człowieka w Rosji i na Zachodzie wielu prokremlowskich ekspertów rosyjskich zachwala rezultaty wprowadzenia nowych przepisów. Szef Centrum Politycznej Informacji Aleksiej Muchin podkreślił, że ustawa spowodowała odstąpienie od używania czarnego PR przez organizacje pozarządowe, które przychylność zagranicznych darczyńców chciały zdobyć przez krytykę obecnej władzy rosyjskiej ${ }^{32}$.

W maju 2015 roku prawo dotyczące organizacji pozarządowych uległo dalszemu zaostrzeniu. Putin podpisał wówczas ustawę pozwalającą władzom Rosji uznać międzynarodowe organizacje pozarządowe oraz firmy za niepożądane na terytorium FR. Taki status może otrzymać organizacja albo firma „stwarzająca zagrożenie dla podstaw ustroju konstytucyjnego Rosji, jej obronności lub bezpieczeństwa"33.

„Zdrajca narodu”, „zagraniczny agent”, „piąta kolumna” to typowe zwroty totalitarnej nowomowy oznaczające wroga obiektywnego - mogą być nimi wszyscy ci, którzy obiektywnie przeszkadzają klasie rządzącej ${ }^{34}$.

Zamknięty język mowy totalitarnej coraz bardziej charakteryzuje współczesny rosyjski dyskurs oficjalny i publicystyczny. Rzeczywistość w niej jest wyraźnie zarysowana. Nie ma miejsca na swobodną interpretację. Jak zaznacza Jakub Sadowski, język kultury totalitarnej to system semiotyczny o bardzo wysokim stopniu zamkniętości, czyli system pokrewny np. językowi znaków

${ }^{30}$ Ю. Маловерьян, „Единая Россия” выдвинула Путина в президенты, http://www. bbc.com/sian/mobile/russia/2011/11/111127_yedinaya_putin_candidacy.shtml [27.10.2015].

${ }^{31}$ Год российскому закону об «иностранных агентах», http://www.golos-ameriki.ru/content/ amnesty-international-ngo/1794107.html [22.10.2015].

32 Закон об иностранных агентах упорядочил работу НКО, http://ria.ru/society/20140214/994 858381.html [dostęp: 08.04.2014].

${ }^{33}$ Putin podpisal ustawę, która pozwala wyrzucać zagraniczne organizacje pozarzadowe z Rosji, http://wpolityce.pl/swiat/245641-putin-podpisal-ustawe-ktora-pozwala-wyrzucac-zagraniczneorganizacje-pozarzadowe-z-rosji [09.10. 2015].

${ }^{34}$ М. Ямпольский, Новинка сезона: «национал-предатели», http://www.newtimes.ru/ articles/ detail/80877/\#hcq=c6IQ7sp [13.10.2015]. 
drogowych. Znak zakazu przekraczania prędkości to przecież wzór z jedną zmienną. Niezależnie od tego, jaką wartość wpiszemy w jasne pole otoczone czerwoną obwódką, istota komunikatu się nie zmieni: nie wolno przekraczać wskazanej prędkości jazdy ${ }^{35}$.

Język totalitarny będący zaprzeczeniem wieloznaczności jest więc daleki od przekazów artystycznych. Słusznie więc Borys Uspienski i Jurij Łotman zaznaczają „niemożliwość poezji na etapie mitologicznym”, czyli właśnie „w Ramach zamkniętego systemu semiotycznego, przyporządkowującego wartości mitologicznym zmiennym"36.

\section{Podsumowanie}

W procesie dewaluacji niesystemowej opozycji w Rosji wykorzystywany jest konstrukt binarnej struktury wróg-przyjaciel, w której opozycja krytykująca obecnego prezydenta Władimira Putina oraz system przez niego stworzony pozycjonowana jest $\mathrm{w}$ polu wróg. Etykietkowanie w ten sposób rosyjskiej opozycji niesystemowej ułatwia elicie kremlowskiej wskazywanie elementów jej ideowego powinowactwa $\mathrm{z}$ obarczanym odpowiedzialnością za wszystkie nieszczęścia Rosji - Zachodem. Tym samym opozycja niesystemowa jako wewnętrzny Zachód staje się ,piątą kolumną”, „zdrajcą narodu”, antypatriotycznym podmiotem dążącym do zniszczenia Rosji. Koncepcje te znajdują aprobatę $\mathrm{w}$ społeczeństwie rosyjskim ze względu na silną potrzebę szukania winnych własnych frustracji oraz niezadowolenia $\mathrm{z}$ otaczającej rzeczywistości. Propaganda tym samym pomaga ukierunkować istniejącą złość.

Opisane w artykule działania władz zorientowane na dyskredytację opozycji niesystemowej oraz dobór środków służących temu celowi stają się egzemplifikacją występowania we współczesnej Rosji elementów totalitarnej gnozy politycznej w dojrzałej postaci. Zwolennicy obecnego prezydenta oraz prokremlowskie środki masowej informacji budują narrację, w której Władimir Putin występuje w charakterze zbawiciela i ojca narodu ${ }^{37}$, pierwszego patrioty w kraju, dzięki któremu Rosja chroniona jest od burzących ład i porządek społeczno-polityczny kolorowych rewolucji. Prezydent jednak nieustannie musi zmagać się siłami Zła i Mroku, czyli Zachodu i współpracujących z nim liderów opozycji niesystemowej. To sprawia, że tym samym wszelkie jego decyzje prowadzące do ograniczenia

\footnotetext{
${ }^{35}$ J. Sadowski, Między Pałacem Rad a Pałacem Kultury..., s. 53.

${ }^{36}$ Tamże, s. 54.

${ }^{37}$ Warto w tym miejscu wspomnieć choćby dokument Prezydent wyemitowany w kwietniu 2015 roku w państwowej telewizji rosyjskiej „Rossija 1” z okazji piętnastolecia rządów Władimira Putina w Rosji, zob. O. Nadskakuła, Prezydent ,zbawicielem ” Rosji, http://stosunki.pl/?q=content/prezydent$\%$ E2\%80\%9Ezbawicielem\%E2\%80\%9D-rosji [26.10.2015].
} 
wpływu i możliwości działania tych sił wydają się w pełni uprawomocnione. Wykorzystywanie języka mowy totalitarnej w toku dewaluacji opozycji niesystemowej wydaje się zabiegiem bardzo niebezpiecznym, prowadzącym do radykalizacji nastrojów społecznych oraz przekonania, że pluralizm poglądów zagraża Rosji, a każdy myślący inaczej niż decydenci polityczni jest zdrajcą narodu, którego należy zniszczyć. Z historii wiemy czym mogą zakończyć się takie przekonania podzielane przez zdecydowaną większość społeczeństwa. Jak słusznie zauważył kiedyś William Isaac Thomas: „Sytuacje uważane przez ludzi za rzeczywiste mają rzeczywiste konsekwencje”. 


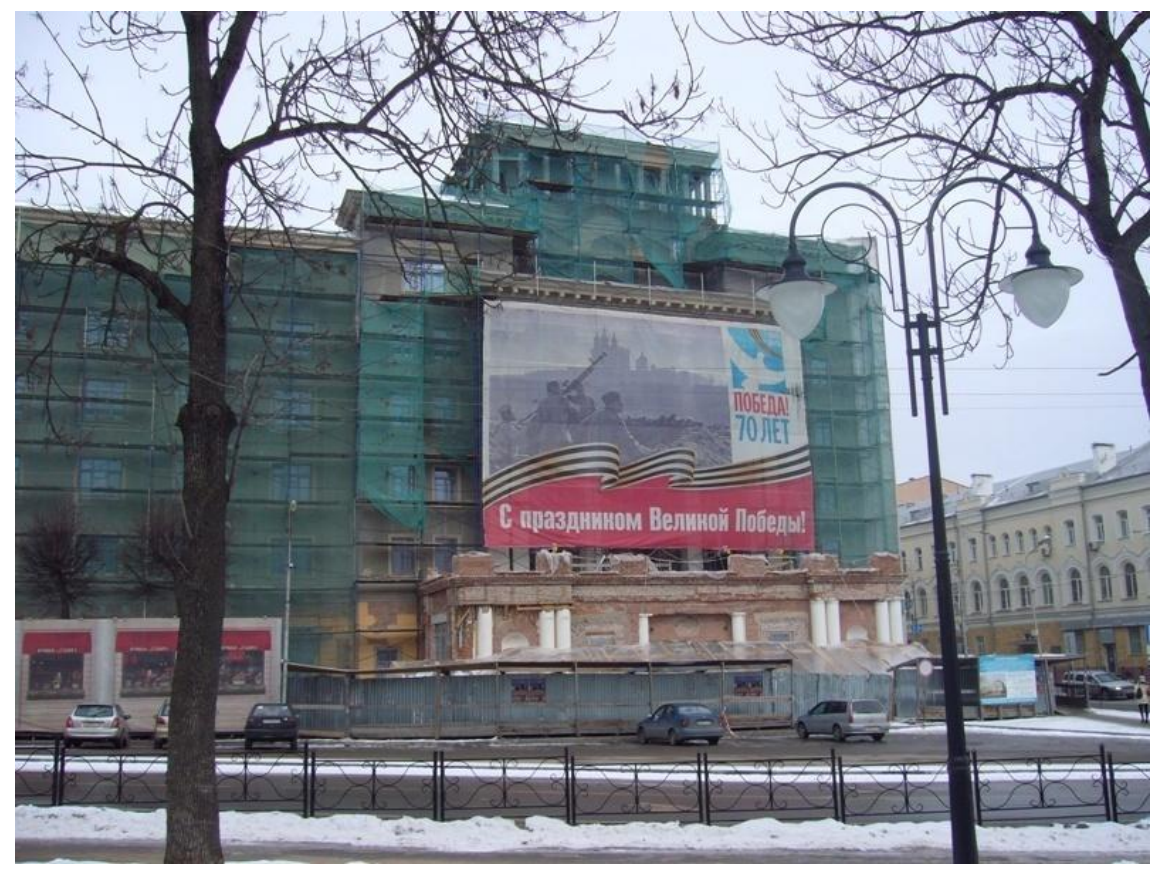

fot. M. Żakowska

„Wszystkiego najlepszego z okazji święta Wielkiego Zwycięstwa!” Baner umieszczony w centrum Smoleńska, upamiętniający siedemdziesiątą rocznicę zwycięstwa ZSRR w II wojnie światowej. Zdjęcie wykonano w lutym 2016 r.

Zgodnie z wynikami badań socjologicznych, przeprowadzonych w 2014 r., za najważniejsze wydarzenie w historii Rosji mieszkańcy Federacji Rosyjskiej uważają zwycięstwo ZSRR w II wojnie światowej, która w FR nazywana jest wielką wojną ojczyźnianą. Wspomniało o nim aż $86 \%$ pytanych, proszonych o wymienienie 10 wydarzeń z rodzimej historii, których daty powinien znać każdy Rosjanin. Na drugim miejscu (67\% głosów) wymieniono pierwszy lot człowieka w kosmos, a na trzecim chrzest Rusi Kijowskiej (66\%). Na trzynastym miejscu (25\% odpowiedzi) padła odpowiedź - ,przyjęcie obecnie obowiązującej konstytucji FR, 38 .

38 Какие даты российской истории мы считаем важнейшими? И какие - знаем?, http://fom.ru/Proshloe/11896 [dostęp: 17.08.2016]. 


\section{Bibliografia}

Bäcker R., Język a władza. Między totalitarna gnoza polityczna a statokratyzmem. Język oficjalnych wypowiedzi państwowo-partyjnych funkcjonariuszy PRL w latach 1981-1989, [w:] Kulturowe instrumentarium panowania, red. P. Załęcki, R. Paradowski, Torun 2001.

Chawryło K., Antymajdan $w$ Rosji - nowy instrument Kremla $w$ walce $z$ opozycja, http://www. osw.waw.pl/pl/publikacje/analizy/2015-01-21/antymajdan-cw-rosji-nowy-instrument-kremla-wwalce-z-opozycja [dostęp: 23.10.2015].

Glowiński M., $O$ dyskursie totalitarnym, [w:] tenże, Dzień Ulissesa $i$ inne szkice na tematy niemitologiczne, Kraków 2000.

Jurij Afanasjew: Chciatbym odczarować Rosję [Adam Michnik żegna przyjaciela], http://wybor cza.pl/magazyn/1,148049,18850836,jurij-afanasjew-chciąłbym-odczarowac-rosje-adam-michnikzegna.html [dostęp: 10.10.2015].

Nadskakula O., Prezydent ,zbawicielem” Rosji, http://stosunki.pl/?q=content/prezydent$\%$ E2\%80\%9Ezbawicielem\%E2\%80\%9D-rosji [dostęp: 26.10 .2015 ]

Niezgoda T., Recepcja Joachima z Fiore $w$ średniowiecznych ruchach heretyckich $w$ świetle koncepcji gnozy politycznej, „Ex nihilo” 2012, 1 (7).

Paniuszkin W., Rosja jakiej nie znacie, https:/www.youtube.com/watch?v=-vbM0ka9QOg [dostęp: 04.12.2014].

Putin podpisal ustawę, która pozwala wyrzucać zagraniczne organizacje pozarzadowe z Rosji, http://wpolityce.pl/swiat/245641-putin-podpisal-ustawe-ktora-pozwala-wyrzucac-zagraniczneorganizacje-pozarzadowe-z-rosji [dostęp: 09.10. 2015].

Sadowski J., Między Pałacem Rad a Pałacem Kultury. Studium kultury totalitarnej, Kraków 2009.

Gnoza polityczna, red. J. Skoczyński, Kraków 1998

Борусяк Л., Левинсон А., Анатомия ненависти: как возникло посткрымское единство россиян, http://www.rbc.ru/opinions/society/18/03/ 2015/550973de9a7947 327e5f3alc [dostęp: 24.10.2015].

Волков Ю., Социальные системы как обект социологическово анализа, „Социс” 2009 nr 9.

Выступление Владимира Путина на заседании клуба „Валдай”, http://www.rg.ru/2013/09 /19/stenogramma-site.html [dostęp: 17.09.2015].

Фельдман Е. в беседе с директором левада-иентра Львом Гудковым. Тоталитарный дрейф, „Новая Газета” 2015, nr 94, 31 sierpnia, zob.http://w ww.levada.ru/31-08-2015/totalitarnyidreif [dostęp: 25.10.2015].

Год российскому закону об «иностранных агентах», http://www.golos-ameriki.ru/content/amnestyinternational-ngo/1794107.html [dostęp: 22.10.2015].

Ямпольский М., Новинка сезона: «национал-предатели», http://www.new times.ru/articles/ detail/80877/\#hcq=c6IQ7sp [dostęp: 13.10.2015].

Какие даты российской истории мы считаем важнейшими? И какие - знаем?, http:// fom.ru/Proshloe/11896 [dostęp: 17.08.2016].

Маловерьян Ю., „Единая Россия” выљвинула Путина в президенты, http://www.bbc.com/ russian/mobile/russia/2011/11/111127_yedinaya_putin_candidacy.shtml [dostęp: 27.10.2015].

Манифест, http://antimaidan.ru/page/9 [dostęp: 12.10.2015].

O возвращении несистемной оппозиции, http://www.ng.ru/editorial/2015-04-21/2_red.html [dostęp: 22.06.2015]. 
Павлова С., Национал-предатели Путина, http://www.svoboda.org/content/article/25302687. html [dostęp: 13.10.2015].

России началось формирование антимайданных дружин, http://izvestia.ru/news/576041 [dostęp: 24.10.2015].

Татаркова Д.Ю., Несистемная оппозициякакспецифика презентации в печатных СМИ, „Полис" 2013, nr 04.

Топорков А.Л., Мифы и мифология XX века: традиция и современное восприятие, http:// www.ruthenia.ru/folklore/toporkov1.htmz [dostęp: 10. 06. 2011].

Шевцова Л., Как Россия возвращает мир к ожиданию войны, http://www.ej.ru/?a=note \&id=24692 [dostęp: 19.09.2015].

Закон об иностранных агентах упорядочил работу НКО, http://ria.ru/society/20140214/994 858381.html [dostęp: 08.04.2014].

\section{"National traitors" - elements of political gnosis in the process of unmasking the internal enemy in Russia}

The aim of this article is to present the image of non-systemic opposition in contemporary Russia, with particular emphasis on marginalization of non-systemic opposition movements by the Kremlin's authority. From the point of view of Kremlin's domestic policy the non- systemic opposition is a national traitor, internal enemy, unpatriotic part of society, which should be destroyed.

The usage of the binary structure „friend and enemy” by Kremlin and its actions against the enemy - the non-systemic opposition, confirms the presence of elements of mature geopolitical gnosis in Vladimir Putin's Russia.

Keywords: Russia, political gnosis, authority 